DOI: 10.26699/jnk.v1i1.ART.p001-006

This is an Open Access article under the CC BY-SA license (http://creativecommons.org/licenses/by-sa/4.0/)

\title{
PENGARUH AVA (AUDIO VISUAL AIDS) TERHADAP KEMAMPUAN LATIHAN PASKA OPERASI LAPAROTOMI
}

\section{(The Effect of Audio Visual Aids (AVA) to the Capability of Exercise Post Laparotomy)}

\author{
Agus Susanto*), Erni Setiyorini**) \\ RSD Mardi Waluyo Blitar \\ e-mail: nerserni@gmail.com
}

\begin{abstract}
Introduction: Health education is the important experience of surgery to client that can used audio visual aids. The purpose of this study was to identify the effect of audio visual aids to the capability exercise post laparotomy. Method: Research design was quasy experiment non equivalent control group design. Research sample was 20 patients whose laparotomy at Mardi Waluyo Hospital Blitar at May 25 $5^{\text {th }}$ until June $16^{\text {th }}$, 2012, its choosed with accidental sampling. The data collected by observation using checklist. Analysis using independent sample T-Test, with $\leq 0.05$ significant level. Result: The results showed that audio visual aids at health education influence capability exercise post laparatomy, with $p$ value 0.000. Discussion: Using tool and method appropriate at health education pre operatif effective to improve output learning.
\end{abstract}

Keywords: audio visual aids, exercise, laparotomy

\section{PENDAHULUAN}

Pendidikan kesehatan pada klien merupakan komponen vital dari pengalaman pembedahan. Pendidikan pre operatif dapat dilakukan melalui diskusi, penggunaan alat bantu visual dan demonstrasi. Hal ini didesain untuk membantu dalam memahami pengalaman pembedahan klien, mengurangi kecemasan dan meningkatkan penyembuhan dari pembedahan (Ignatius, 1995).

Masa rawat yang semakin pendek, peningkatan tuntutan waktu bagi perawat, peningkatan jumlah klien dan kebutuhan untuk memberikan informasi yang tepat bagi klien, semakin menekankan kepentingan kualitas edukasi klien. Perawat terus mencari cara untuk melakukan edukasi klien yang terbaik, sementara masyarakat semakin mampu mencai informasi kesehatan dan menemukan sumber daya yang tersedia di dalam system pelayanan kesehatan. Perawat memberikan informasi kepada klien yang membutuhkan perawatan diri untuk memastikan kontinuitas pelayanan dari rumah sakit (Falvo, 2004).

Pendidikan kesehatan pre operasi ini harus mendeskripsikan tentang berbagai langkah, prosedur dan mencakup penjelasan tentang sensasi yang akan dialami dan latihan - latihan setelah pembedahan yang isinya mencakup beberapa dimensi yang harus diajarkan kepada klien yaitu: latihan (exercise), mobilitas fisik, situasi paska pembedahan, physical support, sensory dan kenyamanan (Brunner \& Suddart, 2002). Disinilah peran perawat dalam membuat kontribusi yang signifikan dalam menunjukkan manfaat pendidikan dan persiapan perioperatif dan mempromosikan hasil yang positif pada klien setelah menjalani operasi atau pembedahan. Pendidikan perioperatif yang terstruktur dan demonstrasi latihan perioperatif telah meningkatkan hasil akhir seperti tingkat nyeri, fungsi paru, lama tinggal dan tingkat kecemasan klien.

Menurut Long, 1996 dalam Nursalam, 2008 menyatakan bahwa pendidikan kesehatan pada pasien 


\section{Agus Susanto, Erni Setiyorini}

preoperasi sebaiknya diberikan sebelum pasien menjalankan operasi dan pendidikan pasien preoperatif ini didasarkan pada waktu yang tepat. Pendidikan kesehatan yang dilakukan beberapa hari sebelum pembedahan, pasien mungkin tidak ingat tentang apa yang telah diajarkan, sedangkan jika instruksi diberikan terlalu dekat dengan waktu pembedahan pasien mungkin tidak dapat berkonsentrasi karena ansietas atau efek dari medikasi praanestesi (Smeltzer, 2002). Pendidikan selama periode perioperatif sangat penting. Lee et.al, 1998 dalam Smeltzer, 2002 melakukan survei kepada 206 klien yang sudah keluar dari rumah sakit yang sebelumnya di rawat di rumah sakit selama 6 minggu. Hasil dari penelitian ini menunjukkan bahwa kesinambungan dari perawatan dapat ditingkatkan jika klien menerima pendidikan sebelumnya, selama dan sesudah keluar dari rumah sakit. Oleh karena itu, tampaknya ideal untuk mengusahakan pendidikan perioperatif masuk sebelum dan selama tinggal di rumah sakit. Setiap program pengajaran pra operasi termasuk didalamnya penjelasan dan demonstrasi latihan paska operasi yaitu : latihan napas dalam, batuk efektif, berbalik, dan latihan kaki. Latihan ini membantu mencegah komplikasi paska operasi.

Dari studi pendahuluan yang dilakukan peneliti di ruang rawat ini (post op) RSD Mardi Waluyo Blitar pada bulan Maret 2012 dari total jumlah operasi sebanyak 171 kasus, 53 kasus (31\%) dengan tindakan laparotomi. Sedangkan sebanyak 20 sampel pasien yang menjalani pembedahan abdomen (laparotomi sebanyak $80 \%$ belum melakukan latihan (exercise) paska operasi pada hari kedua. Sedangkan sisanya melakukan latihan paska operasi dengan teknik yang salah. Dan dari hasil wawancari dengan klien, mereka mengeluh takut bila nyeri dan takut jahitan lukanya akan lepas serta akan menghambat penyembuhan lukanya. Berdasarkan wawancara dengan petugas, sebagian telah memberikan instruksi dan pendidikan untuk melakukan latihan paska operasi tanpa metode demonstrasi dan pengginaan alat bantu. Pada ruang rawat belum ada protab untuk melakukan pendidikan kesehatan pre operatif berupa latihan paska operasi.

Pada pasien post operasi laparotomi diharapkan dapat melakukan latihan (exercise) sesegera mungkin dengan 5 latihan, seperti latihan pernapasan diafragma, batuk dengan teknik splinting, latihan tungkai, moving dan turning di tempat tidur. Latihan ini dapat dilakukan sejak 8 jam setelah pembedahan setelah pasien sadar, dan pada pasien dengan pembiusan regional biasa. Dilakukan 12 - 24 jam berikutnya setelah efek anastesi hilamng (Brunner \& Suddart, 2002).

Banyak alat pengajaran yang tersedia untuk edukasi klien. Pemilihan alat yang tepat tergantung pada pemilihan metode instruksi, kebutuhan belajar klien, dan kemampuan belajar klien. Penggunaan metode yang tepat dalam pendidikan kesehatan pra operasi akan memberikan hasil pembelajaran yang baik (Potter \& Perry, 2009)

$$
\text { Media pembelajaran sangat }
$$
beraneka ragam. Berdasarkan hasil penelitian para aahli, ternyata berbagai media yang beragam itu hampir semua bermanfaat. Cukup banyak jenis dan media yang telah dikenal dewasa ini, dari yang sederhana sampai yang berteknologi tinggi, dari yang mudah dan sudah ada secara natural sampai kepada media yang harus dirancang sendiri oleh guru. Dari beberapa jenis media yang dan biasa digunakan dalam proses pembelajaran, bahwasanya media audio-visual adalah media yang mencakup 2 jenis media yaitu audio dan visual. Media audio visual adalah media yang mempuanya unsur suara dan unsur gambar. Jenis media ini memiliki kemampuan yang lebih baik, karena meliputu kedua jenis media yaitu media audio dan visual. Pendidikan kesehatan dengan alat bantu audio visual dapat merangsang pendengaran dan penglihatan dalam pmenerima informasi media yang dapat dilihat dan didengar. (Mas'udi, 2010)

Pengembangan program pembelajaran kepada klien yang berbasis pada teknologi informasi dan komputer, merupakan suatu terobosan baru dimana konsep ini dapat mengefisienkan waktu 
asuhan keperawatan yang diberikan kepada mereka. Kebutuhan informasi bersifat individual, dimana setiap klien memiliki waktu kesiapan tersendiri dalam menerima informasi. Melalui sebuah program video learning, klien akan belajar sesuai dengan kesiapan yang telah mereka rasakan untuk menerima informasi (Heiskell, 2010). Pemberian informasi kesehatan dengan berbasis teknologi informasi mendukung upaya Joint Commission to Improve Patient Safety (JCI) guna meningkatkan keselamatan klien dalam pemberian asuhan atau tindakan keperawatan melalui penggunaan teknologi (Yanika, 2011).

Berdasarkan uraian di atas, maka perlu dilakukan kajian tentang pengaruh penggunaan AVA (Audio Visual Aids) dalam pendidikan kesehatan terhadap kemampuan latihan paska operasi pada klien dengan laparatomi.

Rumusan masalah dalam penelitian ini adalah : apakah ada pengaruh penggunaan AVA (audio Visual Aids) dalam pendidikan kesehatan terhadap kemampuan latihan paska operasi pada klien dengan pembedahan abdomen di RSD. Mardi Waluyo Blitar.

Tujuan umum dalam penelitian ini adalah untuk mengetahui pengaruh

\section{BAHAN dan METODE}

Desain penelitiannya quasy eksperiment dengan non equivalent control group design, yaitu mengukur kemampuan melaksanakan latihan paska operasi pada klien paska operasi sebelum dan sesudah penggunaan AVA dalam pendidikan kesehatan pada kelompok perlakuan dan kelompok kontrol. Sampel penelitian ini adalah 20 pasien yang menjalani laparotomi di RSD Mardi Waluyo Blitar bulan Mei sampai dengan bulan Juni 2012, yang diplih dengan teknik sampling aksidental. Variabel bebasnya adalah penggunaan AVA dan penggunaan AVA dalam pendidikan kesehatan terhadap kemampuan latihan paska operasi pada klien dengan pembedahan abdomen di RSD. Mardi Waluyo Blitar. Sedangkan tujuan khusus dalam penelitian ini adalah : 1) Mengidentifikasi kemampuan latihan paska operasi laparotomi sebelum dilakukan pendidikan kesehatan pada kelompok perlakuan dan kontrol 2) Mengidentifikasi perbedaan kemampuan latihan paska operasi pada klien dengan laparotomi pada kelompok perlakuan dan kontrol 3) Menganalisis pengaruh AVA dalam pendidikan kesehatan terhadap kemampuan latihan paska operasi pada klien dengan laparotomi di RSD Mardi Waluyo Blitar.

Manfaat penelitian ini secara teoritis adalah untuk mengembangkan ilmu pengetahuan terkait dengan pengaruh penggunaan AVA dalam pendidikan kesehatan terhadap kemampuan latihan paska operasi laparotomi, secara praktis penelitian ini dapat dijadikan dasar dalam penyusunan standart operating procedures dalam memberikan pendidikan kesehatan pada klien pre operasi.

variabel tergantungnya adalah kemampuan latihan pasien paska operasi laparotomi. Perlakuan dilaksanakan sebelum operasi di ruang perawatan dengan menggunakan AVA yang dilanjutkan dengan pengumpulan data, pengumpulan data paska operasi dilakukan 12-24 jam paska operasi di ruang pemulihan kesadaran. Pengambilan data dilakukan pada kelompok kontrol dan perlakuan. Analisis menggunakan independent sample T- test dengan tingkat kemaknaan $\leq 0,05$.

\section{HASIL PENELITIAN}

Karakteristik pasien paska laparotomi.

Tabel 1 Karakteristik responden

\begin{tabular}{llllllll}
\multicolumn{2}{ll}{ Tabel 1} & Karakteristik responden & & No & Karakteristik & Frekuensi & $\%$ \\
\hline No & Karakteristik & Frekuensi & $\%$ & & Jenis kelamin : & & \\
\hline
\end{tabular}


Tabel 1 Karakteristik responden

Tabel 1 Karakteristik responden

\begin{tabular}{|c|c|c|c|c|c|c|c|}
\hline \multirow{3}{*}{ No } & Karakteristik & Frekuensi & $\%$ & \multirow{2}{*}{ No } & Karakteristik & \multirow{2}{*}{$\begin{array}{c}\text { Frekuensi } \\
2 \\
\end{array}$} & \multirow{2}{*}{$\begin{array}{l}\% \\
10\end{array}$} \\
\hline & \multirow{2}{*}{$\begin{array}{l}\text { - Laki - laki } \\
\text { - } \text { Perempuan }\end{array}$} & 8 & 40 & & - PNS & & \\
\hline & & 12 & 60 & \multirow[t]{3}{*}{5} & Pembedahan ke: & & \\
\hline \multirow[t]{5}{*}{2} & Umur : & & & & -1 & 16 & 80 \\
\hline & $-17-25$ th & 1 & 5 & & $-\quad 2$ & 4 & 20 \\
\hline & $-26-35$ th & 3 & 15 & \multirow[t]{9}{*}{6} & Jenis pembedahan: & & \\
\hline & $-36-45$ th & 8 & 40 & & - Laparotomi & & \\
\hline & $-46-60$ th & 8 & 40 & & eksplorasi & 1 & 5 \\
\hline \multirow[t]{5}{*}{3} & Pendidikan : & & & & $\begin{array}{l}\text { - Section cesarean } \\
\text { - Nefrektomi }\end{array}$ & $\begin{array}{l}4 \\
1\end{array}$ & $\begin{array}{c}20 \\
5\end{array}$ \\
\hline & $-\mathrm{SD}$ & 2 & 10 & & - Salpingo ovarektomi & 2 & 10 \\
\hline & - SLTP & 6 & 30 & & - Herniotomi & 5 & 25 \\
\hline & - SLTA & 8 & 40 & & - Total histerektomi & 1 & 5 \\
\hline & - PT & 4 & 20 & & - Uretrolitotomi & 4 & 20 \\
\hline \multirow[t]{4}{*}{4} & Pekerjaan : & & & & - Apendiktomi & 1 & 5 \\
\hline & - IRT & 7 & 35 & & & & \\
\hline & - Petani & 3 & 15 & & & & \\
\hline & - Wiraswasta & 8 & 40 & & & & \\
\hline
\end{tabular}

Tabel 2. Hasil uji statistik kemampuan latihan paska operasi pada kelompok perlakuan dan kontrol sebelum dan sesudah penggunaan AVA daam pendidikan kesehatan di RSD Mardi Waluyo Blitar bulan Mei - Juni 2012

\begin{tabular}{lcc}
\hline Uji Statistik & Kelompok Perlakuan & Kelompok Kontrol \\
\hline Mean pre test & 2.70 & 2.90 \\
\hline Mean post test & 26.70 & 14.70 \\
\hline Signifikansi T-Test & $\mathrm{p}=0.000$ & $\mathrm{p}=0.000$ \\
\hline
\end{tabular}

Tabel 3. Hasil uji statistik kemampuan latihan paska operasi pada kelompok perlakuan dan kontrol sebelum dan sesudah penggunaan AVA daam pendidikan kesehatan di RSD. Mardi Waluyo Blitar bulan Mei - Juni 2012

\begin{tabular}{lcc}
\hline Uji Statistik & Kelompok Perlakuan & Kelompok Kontrol \\
\hline Mean post test & 26.70 & 14.70 \\
\hline Signifikansi $T$-Test & & $\mathrm{p}=0.000$ \\
\hline
\end{tabular}

PEMBAHASAN

Kemampuan latihan paska operasi pada kelompok perlakuan dan kontrol sebelum pendidikan kesehatan

Hasil penelitian menunjukkan bahwa pada responden baik kelompok perlakuan maupun kelompok kontrol dalam melaksanakan latihan paskaoperasi sebelum mendapatkan pendidikan kesehatan mempunyai nilai rata - rata (mean) yang hampir sama. Pada kelompok perlakuan nilai rata-rata (mean) kemampuan dalam melaksanakan latihan paska operasi adalah sebesar 2,70, sedangkan pada kelompok kontrol 2,90.

$$
\text { Ini menunjukkan bahwa }
$$

kemampuan yang sama dalam melaksanakan latihan paska operasi dan sebelumnya klien memungkinkan belum pernah mendapatkan pendidikan kesehatan tentang latihan paska operasi sebelumnya.

Dalam pre test dapat menentukan apakah peserta didik memiliki keterampilan atau pengetahuan yang menjadi prasyarat dalam menjawab dan melaksanakan pertanyaan yang diberikan. Bertujuan untuk mengetahui peserta didik telah mengetahui isi program pembelajaran. Pre test sangat berguna tertutama dalam menentukan tingkat awal program (Gruendeman, 2006). Nilai hasil dari pre test juga bisa digunakan sebagai pembanding dengan nilai post test.

Kemampuan latihan paska operasi pada kelompok perlakuan dan kontrol

Pada klien paska operasi laparotomi diharapkan dapat melakukan latihan sesegera mungkin dengan 5 latihan seperti 
latihan pernapasan diafragma, latihan batuk dengan teknik splinting, latihan tungkai, moving and turning di tempat tidur. Latihan ini dapat dilaksanakan sejak 8 jam setelah pembedahan atau setelah pasien sadar, dan pada pasien dengan pembiusan regional atau spinal block biasa dilakukan 12 sampai 24 jam berikutnya setelah efek anastesi hilang (Brunner \& Suddart, 2002).

Setelah diberikan intervensi berupa penggunaan AVA dalam pendidikan kesehatan, pada kelompok perlakuan didapatkan nilai rata-rata (mean) post test kemampuan dalam melaksanakan latihan paska operasi lebih besar yaitu 26,70, sedangkan pada kelompok kontrol sebesar 14,70. Ini berarti terdapat perbedaan nilai rata - rata (mean) kemampuan dalam melakukan latihan paska operasi bila dibandingkan antara kelompok perlakuan dan kelompok kontrol.

Hal ini sesuai dengan pendapat Notoatmodjo (2003) pendidikan kesehatan adalah usaha atau kegiatan untuk membantu individu, kelompok atau masyarakat dalam meningkatkan kemampuan (perilaku) mereka, untuk mencepai kesehatan mereka optimal. Dengan pendidikan kesehatan yang diberikan maka pengetahuan yang didapat akan meningkat yang otomatis mempengaruhi kemampuan klien dalam melaksanakan latihan paska operasi.

Berdasarkan uraian diatas ternyata kedua kelompok ternyata sama sama mengalami peningkatan nilai ratarata (mean) kemampuan dalam melaksanakan latihan paska operasi baik pada kelompok perlakuan maupun kelompok kontrol, yang membedakan hanya besar peningkatan yang tidak sama antara kelompok perlakuan dan kontrol. Bila dibandingkan nilai rata - rata (mean) post test kelompok perlakuan lebih besar yaitu 26,70, sedangkan kelompok kontrol 14,70 .

Proses pendidikan kesehatan memiliki tiga komponen utama, yaitu : masukan (input), proses dan hasil (output). Input dalam pendidikan kesehatan ini adalah individu, keluarga, kelompok dan masyarakat yang sedang belajar dengan berbagai masalahnya.
Proses adalah mekanisme dari interaksi terjadinya perubahan kemampuan (perilaku) pada diri subyek belajar. Outputnya adalah hasil belajar berupa kemampuan atau perubahan perilaku dari subyek belajar. Dalam proses pembelajaran ini terjadi pengaruh timbale balik antara berbagai factor, antara lain subyek belajar, pengajar atau fasilitator belajar, metode yang digunakan, alat bantu belajar dan materi atau bahan yang dipelajari (Nursalam, 2008).

Keberhasilan pembelajaran dalam meningkatkan kemampuan latihan paska operasi dipengaruhi oleh beberapa faktor. Beberapa ahli pendidikan mengelompokkkan faktor - faktor yang mempengaruhi proses belajar ini kedalam empat kelompok besar, yaitu factor materi, lingkungan, instrument, dan factor individu subyek belajar. Kondisi individual subyek belajar dibedakan kedalam kondisi fisiologis seperti kekurangan gizi dan kondisi panca indera (terutama pendengaran dan penglihatan) sedangkan untuk mempelajari ketrampilan psikomotor, klien membutuhkan kekuatan dan ketajaman sensorik tertentu.

Berdasarkan data frekuensi karakteristik responden berdasarkan usia, diperoleh data bahwa sebagian besar (40\%) responden berusia $46-60$ tahun, usia tersebut termasuk dalam lansia. Pada tahap perkembangan subjek memiliki cara belajar yang berbeda. Pada lansia mengalami berbagai perubahan fisik dan psikologis. Perubahan tersebut menambah kebutuhan edukasi mereka dan menciptakan hambatan belajar, kecuali jika dilakukan penyesuaian intervensi keperawatan. Perubahan sensorik pada penglihatan dan pendengaran membutuhkan penyesuaian metode pengajaran untuk mengoptimalkan fungsi. Lansia belajar dan mengingat secara efektif jika perawat dapat mengatur kecepatan pengajaran dengan tepat dan jika materi tersebut relevan dengan kebutuhan dan kemampuan pelajar. Lansia memiliki fungsi kognitif dan memori menurun. Penggunaan media audio visual sangat berguna bagi klien dengan masalah - masalah komprehensif membaca dan defisit visual (Potter \& Perry, 2009). Selain itu menggunaan 
media audio visual memiliki berbagai kelebihan yaitu memperjelas penyajian pesan agar tidak terlalu bersifat verbalistis (dalam bentuk kata - kata, tertulis atau lisan), gerak yang terlalu lambat atau terlalu cepat dapat diatur, biasanya berperan dalam pembelajaran tutorial dan bias mengamati lebih dekan obyek yang sedang bergerak sehingga dapat meningkatkan retensi (ingatan).

Pengaruh penggunaan AVA dalam pendidikan kesehatan terhadap kemampuan latihan paska operasi pada kelompok perlakuan dan kontrol

Berdasarkan pada analisis dengan menggunakan independen sample T-test, diperoleh hasil $\mathrm{p}=0,000$. nilai ini lebih rendah dari signifikansi $\alpha=0,05$. Hal ini berarti terdapat pengaruh penggunaan AVA dalam pendidikan kesehatan terhadap kemampuan latihan paska operasi pasien dengan laparatomi.

Hal ini sesuai dengan pendapat Gruendeman (2006) bahwa banyak alat pengajaran yang tersedia untuk edukasi klien. Pemilihan alat yang tepat tergantung pada pemilihan metode instruksi, kebutuhan belajar klien dan kemampuan belajar klien. Dalam pengembangan isi program, tipe alat bantu yang diperlukan untuk mendukung isi tersebut harus dipertimbangkan. Penelitian menunjukkan bahwa $75 \%$ pengetahuan diperoleh melalui visual, $13 \%$ dari pendengaran dan $12 \%$ dari penciuman, rasa dan sentuhan. Multimedia yang mengintegrasikan teks, grafik, animasi, audio dan video mengembangkan proses pengajaran dan pembelajaran ke arah yang lebih dinamik (Suroso, 2008).

Sebagai media dalam pendidikan dan pengajaran, media audio visual mempunyai sifat sebagai berikut: kemampuan untuk meningkatkan persepsi, meningkatkan transfer belajar, memberikan penguatan atau pengetahuan hasil yang dicapai dan meningkatkan retensi (ingatan). Karakteristik media

\section{SIMPULAN dan SARAN SIMPULAN}

Ada pengaruh penggunaan AVA dalam pendidikan kesehatan terhadap audio visual adalah memiliki unsur suara dan unsur gambar.

Promosi kesehatan tidak lepas dari media karena melalui media, pesanpesan yang disampaikan dapat lebih menarik dan dipahami, sehingga sasaran dapat mempelajari pesan tersebut dan sasaran dapat memutuskan untuk mengadopsinya perilaku yang positif (Notoatmodjo, 2003). Menurut Riyana dalam Asyhar (2011) menyatakan bahwa melalui media suatu proses pembelajaran bisa lebih menarik dan menyenangkan. Dengan melihat audio visual sebagai media pembelajaran, peserta didik akan mendapat keuntungan yang signifkan bila belajar dengan menggunakan sumber dan media pembelajaran yang sesuai dengan karakteristik dan gaya belajarnya. Media pembelajaran audio visual dapat membangkitkan motivasi belajar peserta didik,sebab penggunaan media pembelaaran audio visual menjadi lebih menarik dan memusatkan perhatian peserta didik.

Pendidikan kesehatan yang berbasis teknologi informasi menggeser sistem pembelajaran konvensional ke modern. Isi informasi pendidikan kesehatan jika sudah terstandar, misalnya melalui penyamaan persepsi dengan menggunakan SOP (Standart Operating Procedure) di ruangan memberikan jaminan keamanan bagi pasien dan kualitas pelayanan keperawatan.

Penekanan utama dalam pengajaran audio visual adalah pada nilai belajar yang diperoleh melalui pengalaman kongkret, tidak hanya didasarkan atas kata - kata. Penggunaan metode dan alat bantu yang tepat dalam pendidikan kesehatan pra operasi akan memberikan hasil pembelajaran yang baik (Potter \& Perry, 2009).

kemampuan latihan paska operasi pada pasien dengan laparotomi dengan nilai signifikansi $\mathrm{p}=0,000$. 


\section{SARAN}

Klien dan keluarga, diharapkan dapat berperan aktif dalam pendidikan kesehatan pra operatif dan pelaksanaan latihan paska operasi. Institusi Rumah sakit, dapat menyediakan sarana dan

\section{REFERENSI}

Arsyad, A 2007, Media Pembelajaran, Raja Grafindo Persada, Jakarta.

Asyhar, RH 2011, Kreatif

Mengembangkan Media

Pembelajaran, Gaung Persada, Jakarta.

Baradero, M \& Siswadi, Y 2008, Prinsip dan Praktik Keperawatan Perioperatif, EGC, Jakarta.

Brunner, L \& Suddarth, D 2002, Buku Ajar Keperawatan Medical Bedah. Ed 8 Vol 1, Penerjemah: H.Kuncara, A.Hartono, M.Ester, Y.Asih, EGC, Jakarta.

Falvo, D.R. 2004. Effective Patient Education: A Guide to Increased Compliance. Canada: Jones and Bartlett Publishers Canada.

Gruendemann, BJ dan Fernsebner. B 2006, Buku Ajar Keperawatan Perioperatif Vol 1, Penerjemah: dr. Brahm U. Pendit, dkk, Jakarta, EGC.

Gruendemann, BJ dan Fernsebner, B 2006, Buku Ajar Keperawatan Perioperatif Vol 2 Praktik, Penerjemah: dr. Brahm U. Pendit, Jakarta, EGC.

Ignatavicius, DD and Bayne 1991, Medical Surgical Nursing, A Nursing Process Approach, Vol 2: Prinsiple, WB Saunders Company, Philadelphia.

Kozier, B and Erb 1991, Fundamental Of Nursing, Addison -Wesley Company Inc, Philadelphia

Mas'udi, A 2010, 'Pengaruh Pendidikan Kesehatan Melalui Media Audio Visual terhadap Perubahan Pengetahuan, Sikap dan Tindakan Mobilisasi Dini Pada Pasien Paska Operasi Apendiktomi di Ruang Bedah Rumkital Dr. Ramelan', Skripsi Fakultas Keperawatan, Universitas Airlangga, Surabaya.

Muttaqin, A \& Sari, K 2009, Asuhan Keperawatan Perioperatif, Konsep, prasarana yang mendukung pendidikan kesehatan pra operasi, mempertimbangkan pembuatan SOP dalam pendidikan pre operatif.

Proses dan Aplikasi, Salemba Medika, Jakarta.

Notoatmodjo, S 2002, Metodologi Penelitian Kesehatan, Rineka Cipta, Jakarta.

Notoatmodjo, S 2003, Pendidikan dan Perilaku Kesehatan, Rineka Cipta, Jakarta.

Notoatmodjo, S 2003, Promosi dan Ilmu Perilaku, Rineka Cipta, Jakarta.

Nursalam \& Effendi 2008, Pendidikan dalam Keperawatan, Salemba Medika, Jakarta.

Rothrock, C.J 2000, Perencanaan Asuhan Keperawatan Perioperatif, Penerjemah: Maria A. Wijaya Rini, EGC, Jakarta.

Potter dan Perry 2009, Fundamental Keperawatan Buku 1 edisi 7, Salemba Medika, Jakarta.

Saroso, S 2008, Upaya Pengembangan Pendidikan melalui Pembelajaran Berbasis Multimedia, diakses tanggal 5 Juni 2012,

http://www.media.diknas. go.id/media/>.

Smeltzer, C 2002, Medical Surgical Nursing, A Nursing Process Approach Vol 2 Principle, WB Saunders Company, Philadelphia.

Smetzel, C 2009, Fundamental Keperawatan Buku 2 edisi 7, Salemba Medika, Jakarta.

Yanika 2011, The technology Acceptance Model Predicting Nurses' Intention to Use Telemedicine Technology (eICU), Computers Informatics Nursing, diakses tanggal 7 Juni 2012, $<$ http://journals.lww.com,journal>. 